\title{
Cloning and Mapping of a Putative Barley NADPH-Dependent HC-Toxin Reductase
}

\author{
F. Han, A. Kleinhofs, A. Kilian, and S. E. Ullrich \\ Departments of Crop and Soil Sciences and Genetics and Cell Biology, Washington State University, Pull- \\ man 99164-6420 \\ Received 16 September 1996. Accepted 20 November 1996.
}

The NADPH-dependent HC-toxin reductase (HCTR), encoded by $\mathrm{Hml}$ in maize, inactivates HC-toxin produced by the fungus Cochliobolus carbonum, and thus confers resistance to the pathogen. The fact that $C$. carbonum only infects maize (Zea mays) and is the only species known to produce HC-toxin raises the question: What are the biological functions of HCTR in other plant species? An HCTR-like enzyme may function to detoxify toxins produced by pathogens which infect other plant species (R. B. Meeley, G. S. Johal, S. E. Briggs, and J. D. Walton, Plant Cell, 4:71-77, 1992). HmI homolog in rice (Y. Hihara, M. Umeda, C. Hara, Q. Liu, S. Aotsuka, K. Toriyama, and H. Uchimiya, unpublished) and HCTR activity in barley, wheat, oats and sorghum have been reported $(R$. B. Meeley and J. D. Walton, Plant Physiol. 97:1080-1086, 1993). To investigate the sequence conservation of $\mathrm{Hml}$ and HCTR in barley and the possible relationship of barley $\mathrm{Hml}$ homolog to the known disease resistance genes, we cloned and mapped a barley (Hordeum vulgare) Hm1like gene. A putative full-length cDNA clone, Bhm1-18, was isolated from a cDNA library consisting of mRNA from young leaves, inflorescences, and immature embryos. This 1,297-bp clone encodes 363 amino acids which show great similarity $(81.6 \%)$ with the amino acid sequence of HM1 in maize. Two loci were mapped to barley molecular marker linkage maps with Bhm1-18 as the probe; locus $A$ (Bhm1A) on the long arm of chromosome 1, and locus B (Bhm1B) on the short arm of chromosome 1 which is syntenic to maize chromosome 9 containing the $\mathrm{Hm} 2$ locus. The Bhm1-18 probe hybridized strongly to a Southern blot of a wide range of grass species, indicating high conservation of HCTR at the DNA sequence level among grasses. The HCTR mRNA was detected in barley roots, leaves, inflorescences, and immature embryos. The conservation of the HCTR sequence, together with its expression in other plant species (R. B. Meeley and J. D. Walton, Plant Physiol. 97:1080-1086, 1993), suggests HCTR plays an important functional role in other plant species.

Additional keywords: dinucleotide-binding fold; genome synteny; HC-toxin synthetase; phytotoxin; spot blotch.

Corresponding author: F. Han; E-mail: hanfeng @ mail.wsu.edu

Nucleotide and/or amino acid sequencing data have been submitted to GenBank as accession number U77463.
The fungus Cochliobolus carbonum (Helminthosporium carbonum) race 1 causes leaf spot and ear mold on maize (Zea mays L.) and produces a cyclic tetrapeptide, called HC-toxin, that determines pathogenicity and host specificity (Scheffer 1976). Synthesis of HC-toxin is controlled by the Tox2 locus in the fungus (Panaccione et al. 1992), which encodes at least two enzyme activities (HTS-1 and HTS-2) of a cyclic peptide synthetase (Walton 1987; Walton and Holden 1988; ScottCraig et al. 1992). In maize, resistance to the C. carbonum race 1 is governed by the dominant allele at the $\mathrm{Hml}$ locus (Nelson and Ullstrup 1964). An enzyme, called HC-toxin reductase (HCTR), inactivates HC-toxin by NADPH-dependent reduction of an essential carbonyl group (Meeley and Walton 1991). The HCTR is detectable only in extracts from resistant genotypes (Meeley et al. 1992). The Hml gene, which encodes HCTR, was cloned by transposon tagging (Johal and Briggs 1992).

The maize $H m l$ gene was the first plant disease resistance (R) gene to be cloned and is an example of the class of plant $\mathrm{R}$ genes that encode a detoxifying enzyme. Toxin-producing $C$. carbonum strains do not cause disease in maize cultivars carrying the $H M 1$ allele, whereas toxin-deficient $C$. carbonum strains lose their ability to cause disease in maize cultivars that do not carry HM1. Another class of $\mathrm{R}$ genes is characterized by gene-for-gene interactions and function by producing a product that recognizes a specific signal molecule (elicitor) produced by the pathogen. A positive interaction triggers the plant defense responses including hypersensitive cell death at the site of infection (Lamb 1994).

To date, no Hml-like $\mathrm{R}$ genes have been cloned from other plant species. Whether a similar mechanism is involved in detoxifying toxins produced by pathogens in other plant species, and specifically whether HCTR has a similar function in other plant species, is unknown but of great interest. Meeley et al. (1992) hypothesized that an HCTR-like enzyme may function to detoxify toxins produced by pathogens in other plant species. Studies have indicated that gradations in pathogenicity have evolved from a host-non-specific fungal species (e.g., Cochliobolus sativus), giving rise to more virulent, hostspecific fungal species (e.g., C. carbonum) (Pringle 1976; Scheffer 1991). C. carbonum is specialized for growth on maize (Scheffer 1991) and is the only fungal species known to produce HC-toxin (Jones and Dunkle 1993). No HC-toxin has been detected in other species within Cochilobolus such as $C$. heterostrophus, C. miyabeanus, C. sativus, and C. victoriae, or in unrelated fungal species that produce similar cyclic 
tetrapeptides, such as Diheterospora chlamydosporia, Cylindrocladium macrosporum, and Petriella guttulata (Jones and Dunkle 1993). An Hml homologue in rice (Y. Hihara, M. Umeda, C. Hara, Q. Liu, S. Aotsuka, K. Toriyama, and H. Uchimiya, unpublished) and HCTR activities in barley, wheat, oats, and sorghum have been identified (Meeley and Walton 1993). To investigate the sequence conservation of $\mathrm{Hml}$ and HCTR in barley and the possible relationship of barley $\mathrm{Hml}$ homolog to the known disease resistance genes, specifically the gene conferring resistance to the toxin-dependent spot blotch disease of barley caused by the pathogen $C$. sativus, we cloned and mapped a barley $\mathrm{Hml}$-like gene.

\section{RESULTS AND DISCUSSION}

\section{Isolation of cDNA clones.}

PCR amplification of a barley cDNA library with the designed primers yielded several bands including a strong band with the expected size ( 200 bp). This band was cloned into pBluescript $\mathrm{KS}(-)$ and sequenced, revealing high sequence similarity to $\mathrm{Hml}$ (not shown). This clone was subsequently used to screen a cDNA library. Five positive clones (Bhm1-1, Bhm1-2, Bhm1-16, Bhm1-18, and Bhm1-24) were identified by screening an amplified library consisting of $6.4 \times 10^{5} \mathrm{PFU}$. The five clones with inserts from 0.6 to $1.3 \mathrm{~kb}$ were sequenced. Sequencing results showed that Bhm1-1, Bhm1-2, Bhm1-18, and Bhm1-24 were 653, 614, 1279 and 1,065-bp, respectively, and are identical in available sequence except that they have different polyadenylation sites. These clones are presumed to be the products of the same gene. Bhm1-18 had a 43-bp 5' leader sequence prior to the first ATG start codon, an open reading frame of 1,089 bp, and a 125-bp 3' untranslated region prior to poly(A) tail (Fig. 1). The Bhm1-

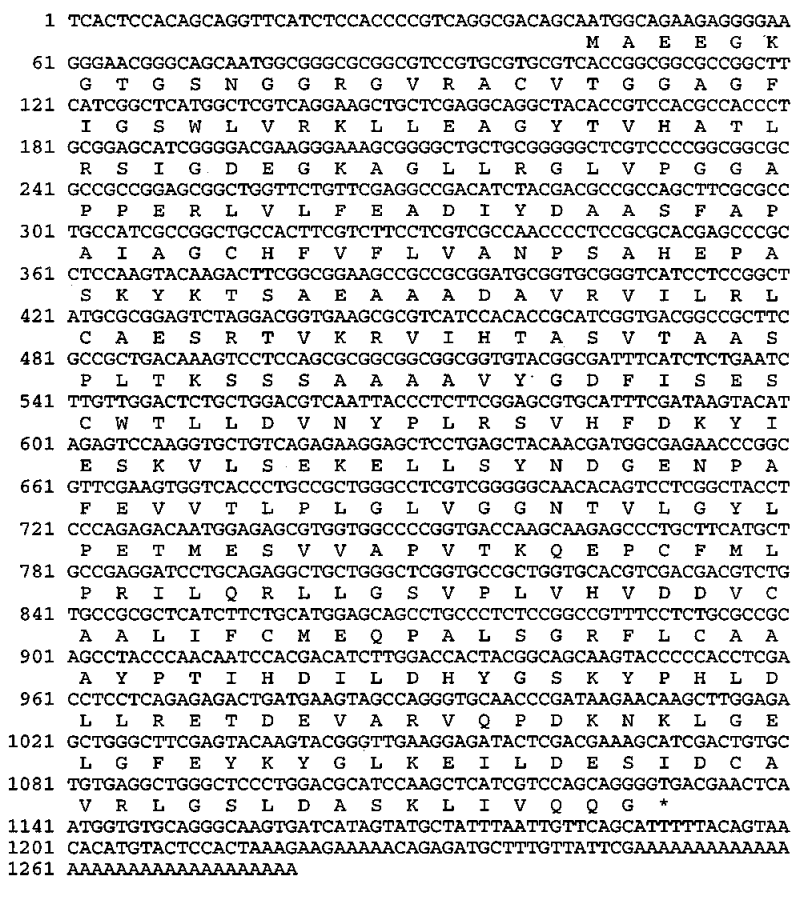

Fig. 1. The nucleotide and derived amino acid sequences of Bhm1-18. The sequence has GenBank accession number U77463.
18 clone is probably full-length, based on analogy with the predicated product of the maize HM1 gene. The fifth clone, Bhm1-16, is 1,065-bp and has a codon (GCC) insertion at position 356-bp from the Bhm1-18 start codon and a codon substitution (from CCC to GCC) next to the inserted codon in comparison with Bhm1-18. This clone may be the product of a very similar gene.

\section{Analysis of amino acid sequence of Bhm1-18.}

The predicted translation product of Bhm1-18 was 363 amino acids long and shared strong homology with HM1 (70.9\% identity and $81.6 \%$ similarity over the entire sequences) (Fig. 2). A long stretch of conserved sequence was found at the $\mathrm{N}$-terminal from amino acids 15 to 48 . There are three overlapped potential $\beta \alpha \beta$-dinucleotide binding folds (I, II, III) (consensus sequence: GXGXXG/AXXXXX-

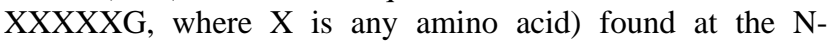
terminal of BHM1-18 (Perham et al. 1991) (Fig. 2). This motif is conserved in NADPH- and NADH-dependent reductases and dehydrogenases. BHM1-18 showed homology to dihydroflavonol-4-reductase (DHFR), a NADPH-dependent carbonyl reductase, from different species, especially at the $\beta \alpha \beta$ dinucleotide binding fold (motif III) (Fig. 3). Based on sequence homology among BHM1-18, HM1, and DHFR, motif III appears to be a functional binding site. The residues Arg125 and Arg-131, which are conserved in virtually all flavoprotein disulphide oxidoreductases that operate with NADPH and in BHM1-18 and HM1, are inferred to be involved in interacting with the 2'-phosphate of NADPH in enzymes utilizing NADP(H) (Perham et al. 1991). Other highly conserved motifs (over 10 amino acids) included amino acids 129-142, 205-217, and 281-294. These conserved motifs may confer substrate specificity of HCTR.

\section{Genetic mapping.}

Hybridization of Bhm1-18 to barley genomic DNA showed one strong band and two to three weaker bands depending on

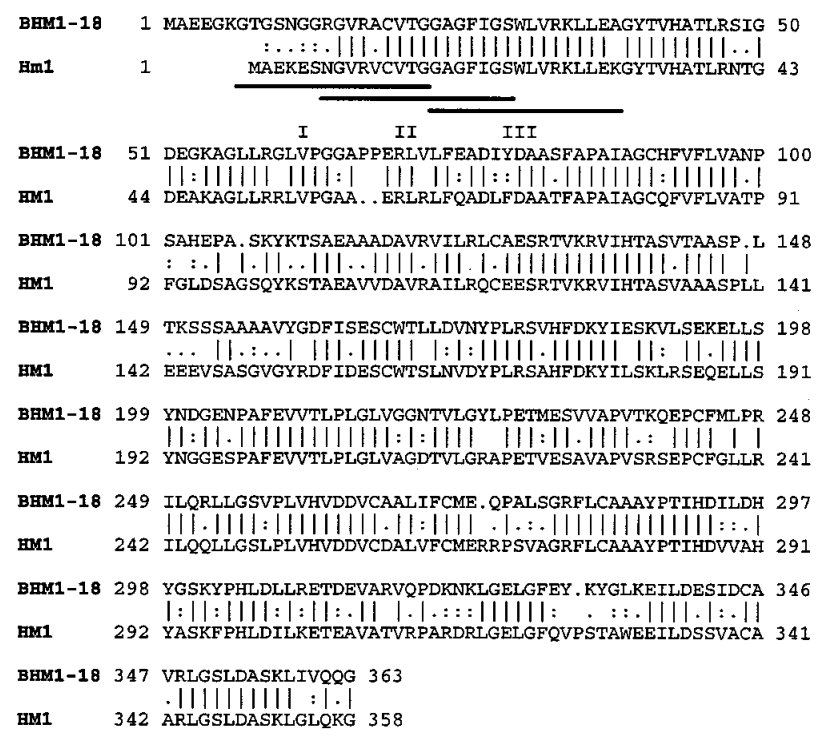

Fig. 2. Alignment of deduced amino acid sequence of BHM1-18 and HM1 with three potential $\beta \alpha \beta$-dinucleotide binding folds (I, II, III) underlined. 
the restriction enzyme used. The hybridization pattern of the other four clones, including Bhm1-16, was the same. The strong band (A) was polymorphic between DraI digested Harrington and TR306, while another, higher molecular weight band (B) was polymorphic between Steptoe and Morex (Fig. 4). These two bands were mapped in the respective crosses revealing two loci designated $\mathrm{Bhm} 1 \mathrm{~A}$ and $\mathrm{Bhm} 1 \mathrm{~B}$ on the minus (long) and plus (short) arms of chromosome 1, respectively (Fig. 5).

There are two loci ( $\mathrm{Hml}$ and $\mathrm{Hm} 2)$ in maize controlling resistance to C. carbonum (Nelson and Ullstrup 1964). In $\mathrm{hml} / \mathrm{hml}$ plants, severity of the disease lesions is determined by the allelic state at the $H m 2$ locus, with $h m 2 / h m 2$ plants being fully susceptible and $\mathrm{Hm} 2 / \mathrm{Hm} 2$ plants being more resistant than $H m 2 / h m 2$ plants. However, Hml alleles are epistatic to $h m 2$ in that $H m l / H m l$ plants are fully resistant regardless of the allelic state at the Hm2 locus (Nelson and Ullstrup 1964). Hml was mapped to maize chromosome 1 (Ullstrup and Brunson 1947), and Hm2 to chromosome 9 (Nelson and Ullstrup 1964). The region containing Hm2 locus of maize chromosome 9 is syntenic to the short arm of barley chromosome 1 containing $\mathrm{Bhm} 1 \mathrm{~B}$, while most of the maize chromosome 1 is syntenic to barley chromosome 4 (Van Deynze et al. 1995). We have also mapped two Hml-like loci on the rice (Oryza sativa) molecular marker linkage map developed by Kurata et al. (1994), one on chromosome 6 in the syntenic region of the barley Bhm1A, and the other on chromosome 7 with synteny to barley chromosome 2 and maize chromosome 7 (Ahn and Tanksely 1993; Van Deynze et al. 1995).

Spot blotch is a common foliar disease of barley and is caused by the pathogen $C$. sativus (Ito and Kurib.) Drechsl. ex Dastur., which also produces phytotoxins including helminthosporal, helminthosporol, and victoxinine (Pringle 1976). Resistance to the spot blotch pathogen is conferred by a single gene at the seedling stage designated Rcs 5 which is mapped to barley chromosome 1P based on both qualitative and quantitative data analyses in the Steptoe/Morex mapping population (Steffenson et al. 1996). Rcs5 is $22.7 \mathrm{cM}$ distal to the $B h m 1 B$. At the adult stage, there is an additional locus identified by quantitative trait locus analysis which is located on chromosome 5P (Steffenson et al. 1996). Many characteristics of $C$. sativus are shared with $C$. carbonum; in fact, these two species are so closely related that they are sexually compatible (Scheffer 1991). However, C. sativus is host-nonspecific, whereas C. carbonum is host-specific (Pringle 1976; Scheffer 1991). PCR primers designed for the C. carbonum HTS-1 (HC-toxin synthetase) coding region failed to amplify a fragment of the expected length from $C$. sativus (Jones and Dunkle 1993). This result, together with evidences that $C$. carbonum may originate from C. sativus (Pringle 1976; Scheffer 1991) and the race 1 of $C$. carbonum is the only race known to produce HC-toxin (Jones and Dunkle 1993) indicates that $C$. sativus is unlikely to produce HC-toxin. Therefore, it is clear that Rcs 5 and $B h m 1 B$ are not the same gene.

\section{Conservation of Bhml in some grass species.}

The Bhm1-18 probe hybridized strongly to a Southern blot of a wide range of grass species, indicating a high conservation of HCTR at the DNA sequence level among the grasses (Fig. 6). Two or more bands were detected in all species, except Hordeum marinum ssp. marinum which had one band and Lolium perenne which lacked a hybridization signal. Hordeum bulbosum, Secale cereale, and Agropyron cristatum showed five to six bands, and strikingly, O. sativa showed 10 distinct bands, suggesting multiple copies of HCTR-like genes in these species.

In maize, resistance to $C$. carbonum appears to differ from susceptibility at the transcriptional level since susceptible genotypes have no hybridization detectable mRNA (Johal and Briggs 1993). Hybridization of the Northern blot with Bhm118 as the probe showed the expression of HCTR mRNA in barley roots, leaves, inflorescences, and immature embryos (data not shown). The amount of HCTR mRNA detected was similar in all tissues, suggesting that the expression of HCTR was not tissue specific. High conservation of HCTR, together with its expression in other plant species (Meeley and Walton 1993), strongly suggests that HCTR must have a biological role in plants other than detoxifying HC-toxin (e.g., possibly inactivating other toxins with a similar structure or functional group). Helminthosporal and helminthosporol are two phytotoxins produced by $C$. sativus. Helminthsporal contains a saturated aldehyde and a $\alpha \beta$-unsaturated aldehyde as functional groups (Mayo et al. 1962), while helminthosporol contains a $\alpha \beta$-unsaturated aldehyde as a functional group (Tamura et al. 1963). The functional carbonyl groups in the helminthosporal and helminthosporol might be reduced by HCTR in detoxification.

Cloning and mapping of the Bhml gene is an initial step to study its biological function in barley. Further genetic, molecular, and biochemical characterization of the Bhml gene and its product, may reveal novel functions of HCTR. Continuing mapping efforts may also identify closely linked or cosegregating phenotypes (possibly disease reaction phenotypes) to $B h m l$, and thus help to elucidate the possible role(s) of Bhml.

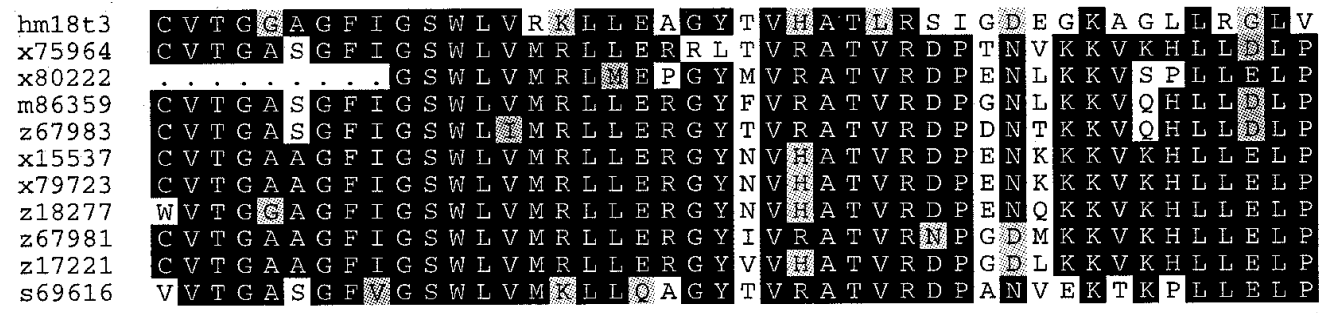

Fig. 3. Sequence alignment of barley putative NADPH HC-toxin reductase with dihydroflavonol-4-reductase from different species at the conserved NADPH binding site. The GenBank accession numbers for the different species (2-11) are X75964, X80222, M86359, Z67983, X15537, X79723, Z18277, Z67981, Z17221, S69616, respectively. 


\section{MATERIALS AND METHODS}

\section{Primer design.}

Based on the conserved sequences between a maize $\mathrm{Hml}$ (GenBank accession no. L02540) and a rice EST with homology to maize Hml (GenBank accession no. D29716), a pair of primers was designed with Oligo primer analysis software (version 3.4). The primers were synthesized at Bio-Synthesis, Inc. Lewisville, TX. The forward primer is $5^{\prime}$-GCGTTCG AGGTGGTG/CACCCT-3', and the reverse primer is $5^{\prime}$-TCCATGCAGAAGACGAGCGC-3'. The PCR product length is 206 bp.

\section{PCR amplification.}

PCR was carried out in a $50-\mu 1$ reaction, containing $5 \mu \mathrm{l}$ of $10 \times$ Taq buffer; $5 \mu \mathrm{l}$ of $1 \mathrm{mM}$ dNTPs; $1.5 \mu \mathrm{l}$ of $50 \mathrm{mM}$ $\mathrm{MgCl}_{2} ; 2 \mu \mathrm{l}$ each of forward and reverse primers (10 $\mathrm{pmol} / \mu \mathrm{l}) ; 1 \mu \mathrm{l}$ of barley cDNA library $\left(1.8 \times 10^{5} \mathrm{PFU} / \mu \mathrm{l}\right)$; and $2.5 \mathrm{U}$ Taq polymerase (GIBCO BRL, Life Technologies, Inc, Gaithersburg, MD). Thermal cycling was performed with a Programmable Thermal Blok II (Lab-Line Instruments, Inc. Melrose, IL): initial denaturation at $94^{\circ} \mathrm{C}$ for $2 \mathrm{~min} ; 30$ cycles (denaturation at $94^{\circ} \mathrm{C}$ for $1 \mathrm{~min}$, annealing at $56^{\circ} \mathrm{C}$ for $30 \mathrm{~s}$, and extension at $72^{\circ} \mathrm{C}$ for $45 \mathrm{~s}$ ); final extension at $72^{\circ} \mathrm{C}$ for 7 min; and, holding at $10^{\circ} \mathrm{C}$.

\section{Cloning of PCR products.}

The PCR products were separated by electrophoresis on $1.5 \%$ agarose gel and visualized under UV light after ethidium bromide staining. The predicted size band was excised from the gel and the DNA was eluted (Dean and Greenwald 1995). The eluted DNA was purified by $95 \%$ ethanol precipitation. A T-overhang cloning vector was made by incubating EcoRV-

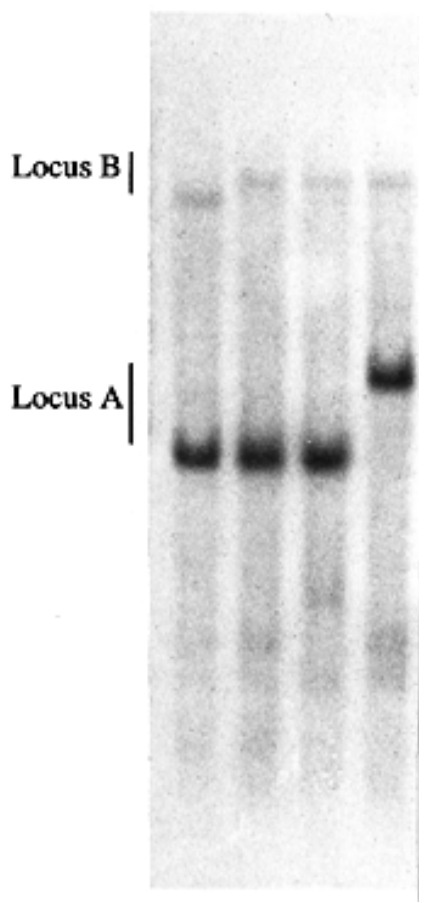

Fig. 4. Southern blot showing polymorphism of Bhm1-18 in four barley genotypes used for producing mapping populations. DNA was digested with $\operatorname{Dra}$ I. Lanes: 1, Steptoe; 2, Morex; 3, Harrington; 4, TR306. digested pBluescript $\mathrm{KS}(-)$ with $5 \mathrm{U}$ Taq polymerase in the presence of $200 \mu \mathrm{M}$ dTTP, $1.5 \mathrm{mM} \mathrm{MgCl}_{2}$, and $1 \times$ standard Taq buffer for $30 \mathrm{~min}$ at $72^{\circ} \mathrm{C}$. Ligation was performed in a 10 $\mu \mathrm{l}$ volume with 20 to $25 \mathrm{ng}$ of purified T-overhang vector and $10 \mathrm{ng}$ of eluted PCR product at $14^{\circ} \mathrm{C}$ overnight. Positive clones were identified by white/blue selection.

cDNA library screening.

A cDNA library was constructed from barley cv. Morex mRNA isolated from young leaves, inflorescences, and im-
SM

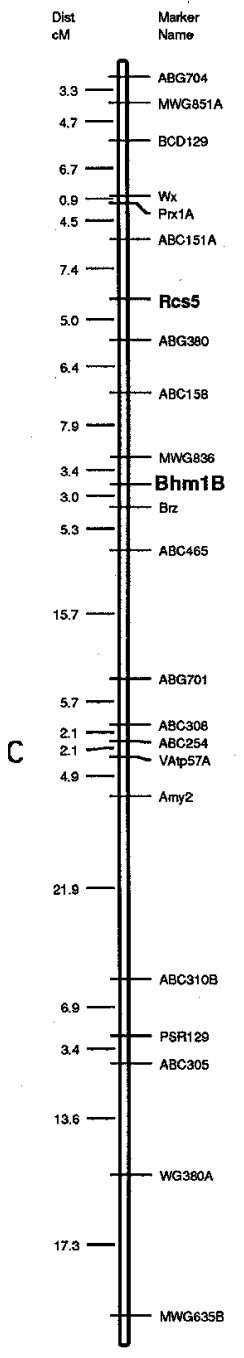

HT

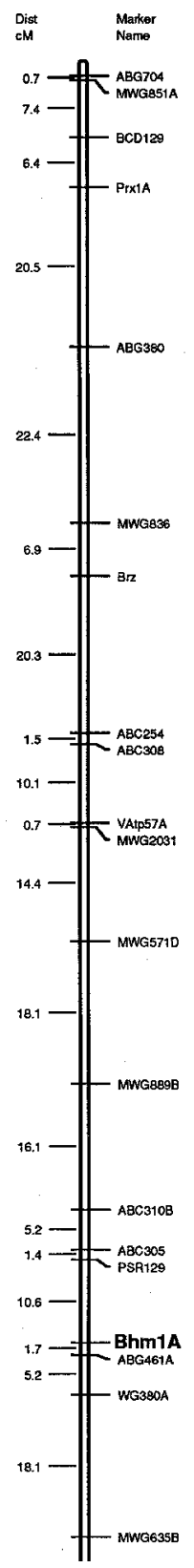

Fig. 5. Steptoe/Mroex (SM) and Harrington/TR306 (HT) skeletal maps of barley chromosome 1 showing location of BhmlA and BhmlB. The maps are aligned at the centromere (C) and many common markers are shown. Note the location of the spot blotch resistance gene Rcs5. 


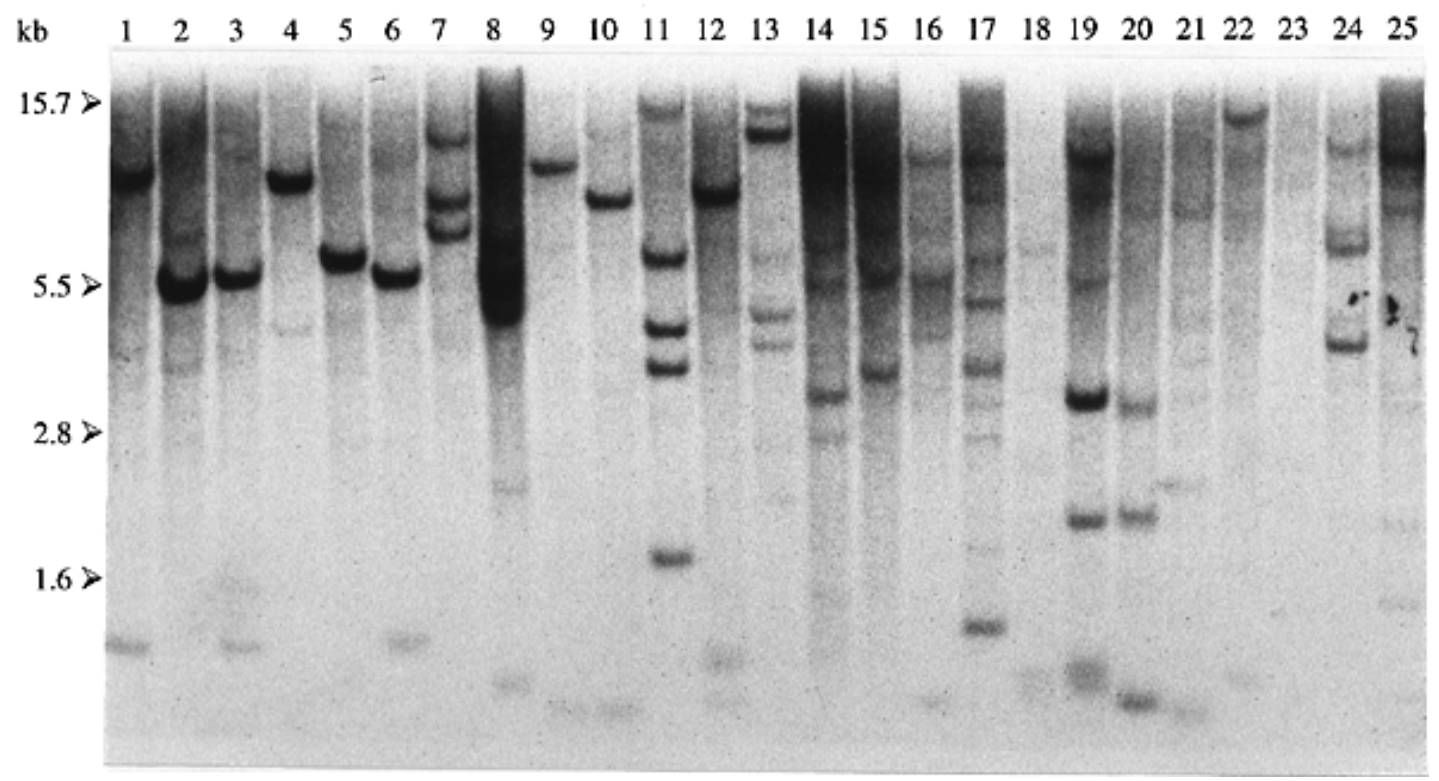

Fig. 6. Southern blot showing hybridization of grass species genomic DNA with Bhm1-18. DNA was digested with $E c o$ RI. The final wash was at $63^{\circ} \mathrm{C}$ with $0.25 \times \mathrm{SSC}$ and $1 \%$ SDS. Film was exposed overnight. Lanes: 1, Hordeum chilense; 2, Hordeum bogdanii; 3, Hordeum stenostachys; 4, Hordeum murinum ssp. glaucum; 5, Hordeum marinum ssp. marinum; 6, Hordeum pusillum; 7, Hordeum murinum ssp. leporinum var. simulans; 8, Hordeum lechleri; 9, Hordeum vulgare ssp. spontaneum; 10, Hordeum vulgare ssp. vulgare; 11, Hordeum bulbosum; 12, Triticum monococcum; 13, Sorghum bicolor $; 14$, Secale cereale $; 15$, Pennisetum americanum; 16 , Avena strigosa $; 17$, Oryza sativa; 18 , Bromus arvensis; 19, Agropyron cristatum; 20, Festuca ovina; 21, Phalaris arundinacea; 22 Psathyrostachys juncea; 23; Lolium perenne; 24, Poa trivialis; 25, Bambusa vulgaris. (ref. to Zhou et al. 1995 for source of plant materials).

mature embryos by Stratagene using the ZAP Express vector and screened with the cloned PCR product. In vivo excision of the $\mathrm{pBK}-\mathrm{CMV}$ phagemid from the ZAP Express vector was performed as described in the 'ZAP Express EcoRI/XhoI library' instruction manual (Stratagene, La Jolla, CA).

\section{Sequencing.}

The positive cDNA clones were sequenced using the ABI dye-primer sequencing kit (Applied Biosystems Inc, Foster City, CA) at the Laboratory for Biotechnology and Bioanalysis, Washington State University.

\section{Genetic mapping.}

Two mapping populations derived from the crosses 'Steptoe' $\times$ 'Morex' and 'Harrington' $\times$ 'TR306' have been used by the North American Barley Genome Mapping Project to construct comprehensive molecular marker linkage maps (Kleinhofs et al. 1993; Kasha et al. 1994). These two populations, each consisting of 150 doubled haploid lines, were used for mapping as previously described (Kleinhofs et al. 1993).

\section{Computer analysis.}

The Genetic Computer Group (GCG) (Madison, WI) programs (Devereux et al. 1984) were used to compile and analyze the DNA sequence information. Genetic mapping was performed using MAPMAKER (Lander et al. 1987).

\section{ACKNOWLEDGMENTS}

This paper is published as Department of Crop and Soil Sciences Scientific Paper Number 9608-09, College of Agriculture and Home Eco- nomics Research Center, Washington State University, Pullman, WA, Projects 0196 and 1006. We are grateful for the financial support of American barley growers, the malting and brewing industry, and USDACSREES Special Grant Agreement 94-34213-0030.

\section{LITERATURE CITED}

Ahn, S., and Tanksley, S. D. 1993. Comparative linkage maps of the rice and maize genomes. Proc. Natl. Acad. Sci. USA 90:7980-7984.

Dean, A. D., and Greenwald, J. E. 1995. Use of filtered pipet tips to elute DNA from agarose gel. BioTechniques 18:980.

Devereux, J., Haeberli, P., and Smithies, O. 1984. A comprehensive set of sequence analysis programs for the VAX. Nucleic Acids Res. 12:387-395.

Johal, G. S., and Briggs, S. P. 1992. Reductase activity encoded by the HM1 disease resistance gene in maize. Science 258:285-987.

Jones, M. J., and Dunkle, L. D. 1993. Analysis of Cochliobolus carbonum races by PCR amplification with arbitrary and gene-specific primers. Phytopathology 83:366-370.

Kasha, K. J., and Kleinhofs, A. 1994. Mapping of the barley cross Harrington $\times$ TR306. Barley Genetics Newsl. 23:65-69.

Kleinhofs, A., Kilian, A., Saghai Maroof, M. A., Biyashev, R. M., Hayes, P., Chen, F. Q., Lapitan, N., Fenwich, A., Blake, T. K., Kanazin, V., Ananiev, E., Dahleen, L., Kudrna, D., Bollinger, J., Knapp, S. J., Liu, B., Sorrells, M., Heun, M., Franckowiak, J. D., Hoffman, D., Skadsen, R., and Steffenson, B. J. 1993. A molecular, isozyme and morphological map of the barley (Hordeum vulgare) genome. Theor. Appl. Genet. 86:705-712.

Kurata, N., Nagamura, Y., Yamamoto, K., Harushima, Y., Sue, N., Wu, J., Antonio, B. A., Shomura, A., Shimizu, T., Lin, S. Y., Inoue, T., Fukuda, A., Shimano, T., Kuboki, Y., Toyama, T., Miyamoto, Y., Kirihara, T., Hayasaka, K., Miyao, A., Monna, L., Zhong, H. S., Tamura, Y., Wang, Z. X., Momma, T., Umehara, Y., Yano, M., Sasaki, T., and Minobe, Y. 1994. A 300-kilobase interval genetic map of rice including 883 expressed sequences. Nature Genet. 8:365-372.

Lamb, C. J. 1994. Plant disease resistance genes in signal perception and transduction. Cell 76:419-422.

Lander, E. S., Green, P., Abrahamson, J., Barlow, A., Daly, M. J., Lin- 
coln, S. E., and Newburg, I. 1987. MAPMAKER: An interactive computer package for constructing primary genetic linkage maps of experimental and natural populations. Genomics 1:174-181.

Mayo, P.de., Spencer, E. Y., and White, R. W. 1962. The constitution of helminthosporal. J. Am. Chem. Soc. 84:494-495.

Meeley, R. B., and Walton, J. D. 1991. Enzymatic detoxification of HCtoxin, the host-selective cyclic peptide from Cochliobolus carbonum. Plant Physiol. 97:1080-1086.

Meeley, R. B., Johal, G. S., Briggs, S. E., and Walton, J. D. 1992. A biochemical phenotype for a disease resistance gene of maize. Plant Cell 4:71-77.

Meeley, R. B., and Walton, J. D. 1993. Molecular biology and biochemistry of $H m 1$, a maize gene for fungal resistance. Pages 463-467 in: Advances in Molecular Genetics of Plant-Microbe Interactions. Vol. 2. E. W. Nester, and D. P. S. Verma, eds. Kluwer Academic Press, Dordrecht.

Nelson, O. E., and Ullstrup, A. J. 1964. Resistance to leafspot in maize; genetic control of resistance to race 1 of Heminthosporium carbonum Ull. J. Hered. 55:195-199.

Panaccione, D. G., Scott-Craig, J. S., Pocard, J. A., and Walton, J. D. 1992. A cyclic peptide synthetase gene required for pathogenicity of the fungus Cochliobolus carbonum on maize. Proc. Natl. Acad. Sci. USA 89:6590-6594.

Perham, R. N., Scrutton, N. S., and Berry, A. 1991. New enzymes for old: Redesigning the coenzyme and substrate specificities of glutathione reductase. BioEssays 13:515-525.

Pringle, R. B. 1976. Comparative biochemistry of the phytopathogenic fungus Helminthosporium. XVI. The production of victoxinine by $H$. sativum and $H$. victoriae. Can. J. Biochem. 54:783-787.

Scheffer, R. P. 1976. Host-specific toxins in relation to pathogenesis and disease resistance. Encycl. Plant Physiol. 4:247-269.

Scheffer, R. P. 1989. Ecological consequences of toxin production by
Cochliobolus and related fungi, Pages 285-300 in: Phytotoxins and Plant Pathogenesis. A. Graniti, R. D. Durbin, and A. Ballio, eds. Springer-Verlag, Berlin.

Scheffer, R. P. 1991. Role of toxins in evolution and ecology of plant pathogenic fungi. Experientia (Basel) 47:804-811.

Scott-Craig, J. S., Panaccione, D. G., Pocard, J. A., and Walton, J. D. 1992. The cyclic peptide synthetase catalyzing HC-toxin production in the filamentous fungus Cochliobolus carbonum is encoded by a 15.7-kilobase open reading frame. J. Biol. Chem. 267:2604426049.

Steffenson, B. J., Hayes, P. M., and Kleinhofs, A. 1996. Genetics of seeding and adult plant resistance to net blotch (Pyrenophora teres $\mathrm{f}$. teres) and spot blotch (Cochliobolus sativus) in barley. Theor. Appl. Genet. 92:552-558.

Tamura, S., Sakurai, A., Kainuma, K., and Takai, M. 1963. Isolation of helminthosporol as a natural plant growth regulator and its chemical structure. Agric. Biol. Chem. 27:738-739.

Ullstrup, A. J., and Brunson, A. M. 1947. Linkage relatonships of a gene in corn determining susceptibility to a Helminthosporium leaf spot. Four. Am. Soc. Agron. 39:606-609.

Van Deynze, A. E., Nelson, J. C., Yglesias, E. S., Harrington, S. E., Braga, D. P., McCouch, S. R., and Sorrells, M. E. 1995. Comparative mapping in grasses. Wheat realtionships. Mol. Gen. Genet. 248:744754.

Walton, J. D. 1987. Two enzymes involved in biosynthesis of the hostselective phytotoxin HC-toxin. Proc. Natl. Acad. Sci. USA 84:84448447.

Walton, J. D., and Holden, F. R. 1988. Properties of two enzymes involved in the biosynthesis of the fungal pathogenicity factor HCtoxin. Mol. Plant-Microbe Interact. 1:128-134.

Zhou, J. Z., Kilian, A., Warner, R. L., and Kleinhofs, A. 1995. Variation of nitrate reductase genes in selected grass species. Genome 38:919-927. 